\title{
Corporate Social Responsibility as a Strategic Shield Against Costs of Earnings Management Practices ${ }^{*}$
}

\author{
Jennifer Martínez Ferrero ${ }^{\dagger}$ \\ Shantanu Banerjee ${ }^{\ddagger}$ \\ Isabel María García Sánchez
}

\begin{abstract}
* The authors wish to acknowledge the financial support of the Ministry of Science and Innovation for the research project ECO2010-15587 and Ethical Investment Research Services (EIRIS) Ltd. Any errors included in this paper are sole responsibility of the authors.
\end{abstract}

${ }^{\dagger}$ Corresponding Author: Departamento de Administración y Economía de la Empresa. Facultad de Economía y Empresa. Edificio FES. Salamanca, 37007, SPAIN.

tel: +34(0) 923294400 Ext. 3132, e-mail: <jenny_marfe@usal.es>

${ }^{\ddagger}$ Department of Accounting and Finance, Lancaster University, Lancaster, LA1 4YX, UK, tel: +44(0) 15245 93200, fax: +44(0) 1524 847321, e-mail: <s.banerjee@lancs.ac.uk>.

\# Departamento de Administración y Economía de la Empresa. Facultad de Economía y Empresa. Edificio FES. Salamanca, 37007, SPAIN.

tel: +34(0) 923294400 Ext. 3115, e-mail: <lajefa@usal.es> 
Corporate Social Responsibility as a Strategic Shield against Costs of Earnings Management Practices

\begin{abstract}
We highlight how Corporate Social Responsibility (CSR) can be strategically used against the negative perception from earnings management (EM). Using international data, we analyse the effect of CSR and EM on the cost of capital and corporate reputation. Results confirm that CSR strategy is positively valued by investors and other stakeholders. Contrary to EM, CSR has a positive effect on corporate reputation and lowers the cost of capital. In addition, we also find that the favorable effect of CSR on cost of capital is consistently more intense in firms that show signs of EM indicating that the market does not identify when CSR practices are used as a strategy to mask EM. We also demonstrate how institutional factors influence the above relationship.
\end{abstract}

KEY WORDS: Earnings Management (EM); Corporate Social Responsibility (CSR); Cost of Capital; Corporate Reputation; Managerial Discretion. 


\section{Introduction}

The emphasis on accounting discipline has increased sharply over the past decade and it forms the basis of good corporate governance. Corporate behavior is scrutinized more intensively by all stakeholders including the regulators and the financial press. In our paper, we focus on Earnings Management (EM) practices and Corporate Social Responsibility (CSR). According to Zahra et al. (2005), the consequences of these discretionary practices affect investors, employees, customers and the local communities, which is eventually reflected in corporate reputation and, hence, the market value. Improvements in Earnings Quality lower information asymmetry and affect the cost of capital (Francis et al., 2005, 2008a; Bhattacharya et al., 2003; Blanco et al., 2009). Furthermore, accounting practices could affect the value of companies, their stakeholder relationships, reputation and corporate image (Fombrun et al., 2000; Roychowdhury, 2006).

On the other hand, Corporate Social Responsibility (CSR) is playing an increasingly important part in the overall corporate strategy. But the reasons for companies to engage in these activities are still unclear and some articles point out that it decreases shareholders' equity (McWilliams and Siegel, 2001). Others argue that CSR is a crucial strategic element for success in product market competition and it increases sales revenue, improves the company's reputation (Sen and Bhattacharya, 2001) and reduces the market's perception of its business risk leading to a lower cost of capital.

These benefits have led to a dramatic growth of CSR practices in the industry, but the suspicion of 'green washing' rather than a whole hearted commitment to social and environmental causes persists. Milne (2013) points out that in spite of a substantial increase 
in claims of sustainable practices by corporations and the communication of the rationale in the past two decades, there has been no real increase in organisational transparency and accountability regarding their impact on the society and the environment. Banerjee (2007) provides a critical perspective by explaining that sustainable practices and CSR is narrowly defined in the financial press and in academic discourses, and the ideology is being used to legitimise the power of large corporations at a cost to societal interests. Delmas et al (2013) point out that most of CSR ratings are developed by small and private organizations with limited transparency about the evaluation process. Furthermore, managers can use CSR practices as a means of self-promotion and personal benefits rather than a discretionary activity that promote sustainable growth going beyond their or the company's own welfare (Handelman and Arnold, 1999; Banerjee, 2007). Prior et al. (2008) and Gargouri et al. (2010), show that managers in companies that indulge in EM are more likely to carry out these discretionary practices, possibly in order to help them secure their jobs and increase compensation. We contribute to this literature by analysing the combined effect of EM and CSR to address whether CSR can be used to mask the effect of aggressive accounting practices on cost of capital and corporate reputation.

Our empirical analysis is based on a large sample of listed companies from 26 countries and covers the period from 2006-2010. The econometric models take account of the level of investor protection and country specific attitudes towards CSR to control for the institutional differences across our sample. EM practices are proxied by discretionary accruals, specifically by the modified Jones model (Dechow et al., 1995), which is the most commonly applied method in the literature. The proxy for CSR is compiled using global data on environment, human rights, stakeholder relations and board composition of companies provided by Ethical Investment Research Service (EIRIS). We measure the implied cost of capital using the price-earnings ratio divided by the short-term earnings growth rate. This 
widely used Price/Earnings to growth ratio (the PEG ratio) was proposed by Easton (2004) and we follow the method in El Ghoul (2011), Botosan and Plumlee (2005), and Blanco et al. (2009) to construct this variable. Finally, we use the Fortune Index to measure Corporate Reputation. Following the method used by Fombrun and Shanley (1990) and Melo and Garrido-Morgado (2012), we create a dummy variable to identify a firm as one of the world's most admired companies based on the top 50 surveys and industry rankings for each year during the sample period.

We use the Arellano and Bond (1991) Generalized Method of Moments (GMM) estimator on the panel data to analyze the effect on cost of capital and use Logit models for Corporate Reputation. We show that EM practices leads to higher costs of capital and lower reputation. Based on the extant literature we argue that this result is driven by the perceived uncertainty resulting in a discounting of the value of the information reported by the company engaging in EM practices. On the contrary, a lower rate of return is demanded by investors whose money is in companies promoting CSR practices, and more importantly the effect is significantly more favorable for firms engaging in EM. We also document that a company's chances of being listed among the world's most admired companies increase when they display positive CSR strategies. Unlike previous literature in this field, these results clearly highlight that CSR activities can be used to mask EM practices. This interpretation is supported by the theoretical arguments that point out that sustainability reporting by companies and the CSR scores, widely used by investors and stakeholders are difficult to decipher and companies might benefi from this information asymmetry and use these communications to clear their image while having little or no real commitment to sustainable practices. Our analyses also show that the firms engaging in EM can avoid being punished through higher risk premium by engaging in CSR activities, particularly in countries with higher investor protection. To check for institutional difference in the pattern of the 
relationships, we divide the sample into civil law and common law countries. The shielding effect of CSR works well in civil law country, but markets in common law countries seem to penalize EM irrespective of CSR credentials.

In the next section, we discuss the related literature and establish a set of testable hypotheses. In section 3, we describe the sample, variables and empirical methodology used to test the hypotheses. Section 4 presents the results of our empirical analysis and discusses them. The concluding section summarises the main findings, point out the limitations of this study and suggest lines for possible future research.

\section{Literature review and hypotheses}

\subsection{Earnings Management, Cost of Capital and Corporate Reputation}

Accounting numbers should aim to portray a realistic picture of the financial flow and stock in the current year and smooth out transitory components to make the statements more representative. But the managers' might intentionally manage accounting results for shortterm personal benefits rather than for the interests of the shareholders and other stakeholders who would usually have a longer horizon (Healy and Wahlen, 1999). EM ${ }^{1}$ may be purely a financial recording decision in which the adjustments are done in the way facts are accounted for, usually by means of provisions, accruals adjustments or changes in criteria and repayment systems. Managers usually prefer this route: they are less visible and less costly, unlike 'real' EM decisions which affect the company's performance and operations, such as the optimal moment for selling or the selection of R\&D projects. As noted by Gargouri et al.

\footnotetext{
${ }^{1}$ The basis of EM practices has been established by the Agency and the Positive Accounting theories. The conflict of interest arising from the separation between ownership and control (which is the basis of the Agency Theory) and information asymmetry between the two parties create a vacuum where managers behave discretionarily, do not take into account shareholders' interests and carry out EM practices. Positive Accounting Theory point out that accounting choice depends on firm characteristics as it is used to help the relationship between the managers and the stakeholders of firms, particularly the investors.
} 
(2010), managers manipulate accounting results to smooth out income flows, to minimise the tax burden, to carry out changes in the control of the company, to influence labour negotiations or to respond to takeover bids. Healy and Wahlen (1999) differentiated these motivations as contractual, political/governmental and value-based. The consequences of these management practices can increase information asymmetry and reduce the value of the company, its reputation and its corporate image (Fombrun et al., 2000). We focus on the consequences of EM practices on the cost of capital and on company reputation.

Cost of capital determines the viability of business models and affects investment decisions and the value of the company fundamentally. A number of previous research papers have pointed out that the earnings quality decreases information asymmetries and the cost of capital (Francis et al., 2005, 2008a; Bhattacharya et al., 2003). Theory suggests that both investors and the market demand a higher rate of return from companies carrying out manipulative practices (Lambert et al., 2007) as these practices increases the perception of uncertainty about their financial health. Furthermore, EM overstate performance temporarily and it can be designed to benefit the myopic managers at a cost to long term investors and stakeholders and these agency costs get reflected in the cost of capital. On the other hand, top-quality financial information and little or no EM practices signals credibility and lowers the information asymmetry between managers and investors and hence, the cost of capital.

We expect to find a positive relationship between EM practices and cost of capital in line with earlier studies by Francis et al. (2004, 2005), Gray et al. (2009), and Blanco et al. (2009):

H1a: Earnings management practices increase the cost of capital.

Reputation could be defined as “a perceptual representation of a company’s past actions and future prospects that describe the firm's overall appeal to all its key constituents 
when compared to other leading rivals” (Fombrun, 1996, p. 72). Corporate Reputation depends on the information received by the public about that company's behavior, via the press, the market or the company itself (Brammer and Pavelin, 2004). Fombrun et al. (2000) and Roychowdhury (2006) point out the negative impact of these discretionary accounting practices on the value of companies, their transactions, their reputation and their corporate image. It also leads to loss of support from investors and other stakeholders, increased activism and surveillance by interest groups and regulatory authorities, damage to corporate reputation and financing constraints (Fombrun et al., 2000). EM not only reduces the reputation of companies, it can also lead to loss of reputation of the individual managers responsible for overseeing the reports when accounting scandals or aggressive EM practices come to light (Zahra et al., 2005). These practices reflect managerial short-sightedness or desperation and influence the concerned parties' opinion about the credibility of the management and the prospects of the company. Empirically, the effect of EM on corporate reputation has not been studied in depth but there is evidence of loss of reputation when small cases of fraud come to light (Francis et al., 2008b).

Our next hypothesis is based on the above logic. We expect a negative relationship between EM and reputation: manipulative accounting practices have a detrimental effect on companies' corporate reputation reflecting the loss of support from investors and nonfinancial stakeholders.

H1b: Earnings management practices decrease corporate reputation.

\subsection{Corporate Social Responsibility, Cost of Capital and Corporate Reputation}

Companies can support the society by developing environmental protection systems and policies and implementing actions to promote relations with their customers, suppliers, employees and the community. CSR practices are appreciated as it generates positive 
externality by going over and above legal requirements, i.e., they are not legally enforceable (Basu and Palazzo, 2008). According to the Stakeholders Theory, alignment of company objectives with that of their stakeholder groups and the community creates a valuable intangible asset that works through various channels to help the company achieve stability and higher growth in the long term (Titman, 1984; Banerjee et al., 2008). The resource-based view of the firm points out that firm performance depends on the interplay of various tangible and intangible resources. Barney (1991) highlights that competitive advantage often depends on assets that are valuable, rare and inimitable and the firms that hold them should be organized to deploy these resources effectively. Stakeholder relationships developed over time and meet these very restrictive criteria and hence should be relevant to parties trying to evaluate long term prospects of the company. The Legitimacy Theory widens the Stakeholders Theory based on the argument that CSR is not only focused on stakeholders' needs and alignment of interests, but on the principles coherent with some socially constructed system of norms, values and beliefs (Gray et al., 1995). Positive CSR strategies promote a climate of legitimacy and support among regulators and stakeholders. They also dissuade activism and intervention by interest groups and increase job satisfaction and customer loyalty (Hong and Andersen, 2011; Scholtens and Kang, 2012). Positive stakeholder relationship leads to loyalty and develops corporate reputation and these can get reflected in higher market share, profits and financial stability in the long term. These effects would work in the same way even if the stakeholders and investors have an incomplete understanding of meaningful CSR and the firm try to manipulate their perception to its advantage. This gives influential profit-making entities, like large corporations, incentive to try to distort the process of evaluation of CSR practices so that they can score highly with little effort or commitment. 
Due to these dynamics, the perception of long-term business risk is reduced for companies that promote and carry out positive social and environmental actions and this may lead to a lower the cost of capital (Gregory et al., 2011). El Ghoul et al. (2010) demonstrate that companies that implement good CSR policies have significantly lower cost of capital, and point out that investors and the market consider these companies less vulnerable and more trustworthy and they have a lower systematic risk. On the other hand, tobacco and nuclear power companies have a higher cost of capital as they are deemed risky due to the (possible) future costs to the community and a backlash effect on them.

Following the above evidence and arguments, we expect the following relationship:

H2a: Positive CSR strategies lead to a decrease in Cost of Capital.

CSR practices are increasingly being recognised as a strategic investment to improve or maintain corporate reputation. According to the stakeholder theory, a company's support to different stakeholder groups creates social capital, which help the company improve its financial stability and long-term performance (Carroll, 1979; Donaldson and Preston, 1995; Post et al., 2002). Loyalty and long-term support of stakeholders reinforces and improves the valuable intangible asset summarised as reputation of the company (Branco and Rodrigues, 2006).

Williams and Barrett (2000) find evidence of a positive relationship between philanthropy and corporate reputation. CSR policies, when perceived as credible, improve the corporate image perceived by customers, suppliers, investors, banks and the market (Sen et al., 2006). These results are supported by Brammer and Pavelin (2004), Lai et al. (2010) and Melo and Garrido-Morgado (2012) who empirically confirm a positive effect of CSR on reputation and point out that corporate reputation is influenced by a wide range of strategies 
of which CSR practices have the most significant effect. In line with the previous arguments and evidence, we proposed the following hypothesis:

H2b: Positive CSR strategies lead to an increase in corporate reputation.

\subsection{Can CSR practices be used as a Strategic Shield against Costs of Earnings}

\section{Management Practices?}

Corporations are profit making entities and very few would subscribe to the idea that they can be persuaded to commit to environment and social policies that benefit the community at a cost to the shareholders and the management. The optimistic view is that CSR practices are long term strategies that benefit all parties and shareholders, with a long horizon, should support them. However, the compensation structure of managers in most corporations is heavily based on current profits and stock price performance and it makes costly long-term strategies unattractive to them. The voluntary nature of these practices and their reporting allows the manager to design them to fit the their own interests rather than to benefit the community and stakeholders (Buhr et al., 2014). Due to this, stakeholders often have a sceptical view on corporate claims about CSR practices (Bakan, 2005; Barnett, 2007 Indeed, managers can simply try to manipulate the perception about their commitment to CSR at minimum cost for short term private benefits at a cost to the community and the long term investors. These practices have been referred to as 'green-washing' in the press. Gray (2006) questions the feasibility and even the desirability of shareholder value creation from positive social, environmental and sustainable practices and highlights the need to challenge

the cosmetic adjustments that the current accounting system encourages. We have witnessed a steady growth in socially responsible investment funds in response to ethically motivated investors, but such funds are designed based on a reductionist view of sustainability that help businesses to perpetuate their profit motive (Entine, 2003; Hawken, 2004; Haigh, 2006). The 
emphasis on CSR scores as a measure of overall sustainable practices by investment managers and stakeholders enables large corporations to play to their strengths and increase the numerical value by concentrating on components they can influence more easily and with lower cost with little or no real care about sustainability. Chatterji et al. (2009) studies the ratings of Kinder, Lydenberg, Domini Research \& Analytics (KLD) which is most widely used in the US and find that they do not use publicly available data optimally and KLD environmental strengths are poor predictor of future pollution and compliance violation. However, since most socially responsible investment strategies are based on these ratings, the resulting investments would reduce cost of capital of firms with high CSR scores reinforcing the notion that CSR increases financial strengths and incentivise corporations to keep on using the cosmetic strategies.

Prior et al. (2008) and Gargouri et al. (2010) report that companies whose managers engage in aggressive accounting policies and EM are more likely to display ethical and social policies. A plausible explanation of this positive association is the managers' aim of obtaining the support of stakeholders and reducing the risk of dismissal triggered by the negative effects of EM practices on the company's value and reputation. Cespa and Cestone (2007) point out that perceived commitment to CSR could, in effect, help to ensure the continuity in their leadership position by empowering them to fight challenges to their control on the company, to undertake labour negotiations and avoid activism and boycotts by various stakeholder groups. Prior et al., (2008) show that CSR is often implemented as a defensive tool to avoid negative reactions and subsequent surveillance by the stakeholders who might be affected by EM, thereby entrenching the managers' position in the company and allowing them to continue acting in their own interest (also see Surroca et al., 2010). 
The possibility that CSR can be used as a shielding or entrenchment strategy to help reduce the negative reaction to EM practices raises the following research question: is the market able to identify the possible use of CSR as a shielding strategy? The market might be able to see through this and penalize these companies leading to a higher cost of capital and lower reputation. But even though investors, market and stakeholders are aware of this possibility, they may not have the necessary information. Insiders might manage earnings to portray a more realistic picture of the financial health of the company, rather than generate short term private benefits. Investors and interest groups might consider investments in CSR as a signal of the company's long term strategy and might discount concerns arising purely from EM practices, resulting in a favorable effect on cost of capital and corporate reputation. In this scenario, CSR activities would not only improve financing constraint and reputation on its own, but can help compensate for loss of confidence from discretionary accounting choices. Because of this shielding effect, managers engaging in EM would find it worthwhile to pursue some degree of positive CSR even if they do not have a long term commitment. If the market sees through this attempt, the gains from investments in CSR would become unattractive to the myopic managers and they might prefer to use the limited resource to improve their bottom-line and accounting quality and we might not see an overall negative association between EM and CSR practices. But the extant literature portrays a consistent positive link between the two and that can be explained from the shielding effect of CSR against costs of EM practices. We test this argument using the following two hypotheses:

H3a: Positive CSR practices can be used strategically to shield against the negative effect of earnings management on the cost of capital.

H3b: Positive CSR practices can be used strategically to shield against the negative effect of earnings management on corporate reputation. 


\subsection{Institutional moderating factors: national approach to CSR and Investor}

\section{Protection}

The operating environment of the corporations plays an important role in their decision making process and we try to capture these institutional factors. Institutional approaches towards CSR differ across countries as they evolve as a result of public pressure or the environmental normative context. According to Kolk and Perego (2008), social, political and regulatory pressure on a specific issue (in this case, CSR) in any country shapes the institutional structure regulating it. For instance, Van Tulder and Van der Zwart (2006) illustrate that the American focus on CSR is neo-liberal and that the essential role played by the government focuses on strongly emphasizing sanctions, rules and laws. This is an instrumental view of CSR. On the contrary, the system in Europe is designed to promote companies’ active role regarding CSR strategy and avoid the level of legal enforcement seen in the United States. As for Asia, the basic rules of CSR largely result from numerous enquiries of big companies, and are caused by the necessity of guaranteeing the international competitiveness of industries. Companies located in areas with strong expectations of voluntary CSR activities are more likely to be identified and penalized by the stakeholders and the market for unacceptable behavior that damage interests of investors and other stakeholders. These will be reflected in the cost of capital and corporate reputation. Thus we expect to observe the following:

H4: The national approach to CSR modifies the direct and shielding effect of CSR practices on Cost of Capital and Corporate Reputation.

The level of investor protection in each country is also important in these relationships because it has been identified as one of the main institutional factors affecting corporate decision making (Shleifer and Vishny, 1997). Companies in countries with higher levels of 
investor protection prioritize shareholder interests, often short term interests, and the effect of CSR on cost of capital and corporate reputation can diverge. On the other hand, agency problems are bigger in companies located in countries where investor protection is low (La Porta et al., 1999) and managers have more room to carry out EM. Accounting practices are less aggressive in countries with more investor protection (Haw et al, 2004, Chih et al., 2008; Scholtens and Kang, 2012), because institutional environments restrict managers' ability to obtain private benefits (Leuz et al., 2003). Companies located in these countries may not identify CSR practices as a shielding strategy because their investors think that laws dealing with investor protection prevent the risk of expropriation by the management through EM.

Following the argument of Prado Lorenzo et al. (2012) and Simnett et al. (2009) we would expect that countries with a lower level of investor protection tend to be more focused on relationship building with stakeholder groups and voluntarily assuming certain social responsibilities. A number of civil law countries, usually classified as countries with low investor protection have a community perspective and are characterized by laws aiming to protect worker's and other concerned parties’ rights (Marginson and Sisson, 1994; Ferrer and Quintanilla, 1998). CSR practices might generate a stronger signal of a long term strategic planning and show a positive relation with firm value in these countries, but we do not expect to see CSR used as a shield against EM simply because investors have limited influence on the mangers. On the basis of the counteractive forces discussed above, we find that it is difficult to make consistent prediction about the effect of investor protection on the shielding effect of CSR influencing cost of capital and corporate reputation, but the coefficients on other relevant factors can be biased if we do not control for investor protection.

\section{METHODOLOGY}

\subsection{Population and sample}


Our sample consists of 1,757 publicly listed non-financial companies for the period 2006-2010 based in one of the 26 countries for which we have adequate data. ${ }^{2}$ This gives us an unbalanced panel of 8,785 firm years. We use the following four publicly available databases to collect the required data: (1) Thomson One Analytic, for accounting and financial data; (2) the Ethical Investment Research Service (EIRIS), for data on CSR and Corporate Governance; and (3) I/B/E/S for analysts’ earnings and long term growth forecasts. The financial information is collected from consolidated statements of the sample of companies. Corporate Reputation is obtained from Fortune magazine (specifically, from the (4) World's most admired companies ranking).

\subsection{Measurement of the Cost of Capital}

The cost of equity capital is the minimum rate of return equity investors require for providing capital to the firm (Botosan, 2006). We use the Price-Earnings-Growth (PEG) ratio as a measure of cost of equity capital based on the Easton (2004) model in a similar way as in Botosan and Plumlee (2005), Francis et al. (2008a), Blanco et al. (2009) and El Ghoul et al. (2011). Our dependent variable is based on the concept of expected Price-Earnings-Growth of Ohlson and Juettner-Nauroth (2003) that was operationalized by Easton (2004). This measure imposes the assumption of zero growth in abnormal earnings beyond the forecast horizon and is more useful since it isolates the effect of growth and cash flow (Hail and Leuz, 2006). The $\boldsymbol{r}_{P E G}$ ratio is calculated as follows:

$$
r_{P E G}=\sqrt{\frac{E P S_{5}-E P S_{4}}{P_{0}}}
$$

where $E P S_{t}$ is the expected earnings per share t years in the future and $P_{0}$ is the current market price of the firm's stock. Following Blanco et al. (2009), we use five years

\footnotetext{
${ }^{2}$ We count the special administrative region of Hong Kong as a separate country to reflect the fact that their corporate environment is different from that of mainland China.
} 
long-term growth rates from $I / B / E / S$ to calculate these earnings per share forecasts in year 4 and 5. The model requires positive four-year-ahead and five-year-ahead earnings forecasts as well as positive change in the earnings forecast.

We use long-term earnings forecasts $\left(E P S_{5}\right.$ and $\left.E P S_{4}\right)$ as in Botosan and Plumee (2005), rather than $E P S_{2}$ and $E P S_{1}$ because of if $E P S_{2}$ is less than $E P S_{1}$, we can not solve the model and limit our sample. However, since $E P S_{5}$ always exceeds $E P S_{4}$ this problem is avoided with the use of $E P S_{5}$ and $E P S_{4}$. They study different measures of cost of capital and conclude that the estimates based on the PEG ratio proposed by Easton (2004) are consistently and predictably related to market risk, leverage risk, information risk, firm size, book-to-price and growth. They argue that this ratio dominates the alternative measures of cost of capital and recommend that analysis that requires estimates of firm-specific cost of equity capital can rely on this measure.

\subsection{Measures of Corporate Reputation}

We compile the data on corporate reputation following a commonly used methodology based on the Fortune Index (Melo and Garrido-Morgado, 2012; Fombrun and Shanley, 1990). The World's most admired companies ranking for the period 2006-2010 gives an alphabetical index of the most admired companies from the top 50 surveys and industry rankings for each year. This Fortune index is based on questionnaire responses from executives, outside directors and security analysts and companies are classified with respect to their competitors using eight attributes of reputation. In our analysis, REPUTATION is a dummy variable with the value of 1 for companies in the World's most admired companies ranking in that year (and 0 otherwise).

\subsection{Measures of Earnings Management}


We measure EM based on the discretionary component of accruals adjustment as this could be used as a measure of discretionary management, and therefore of accounting manipulation. The discretionary accruals adjustment (DAA) is obtained by subtracting the non-discretionary accruals adjustment (NDAA) from the total accruals adjustment (TAA). The DAA represents the abnormal accruals that proxy for $\boldsymbol{E M}$. We use the modified Jones model (Dechow et al., 1995) to separate the non-discretionary component of accruals from the total. It is the most widely accepted and used method in the literature. The measurement procedure of EM practices is explained in detail in Appendix 1. We include dummies that identify the country of origin, because the size of the sample does not allow estimating models by sector and country efficiently. This procedure has been used by authors working with international sample of firms (see Prior et al., 2008 and Chih et al., 2008).

\subsection{Measurement of CSR practices}

CSR practices should be measured using a multidimensional construct addressing all the actions that have been carried out, especially in social and environmental contexts (Carroll, 1999). The CSR information is collected from the EIRIS database. ${ }^{3}$ This database is widely used in the in the industry and in academic research, including Brammer et al. (2006), Scholtens and Dam (2007), Louche et al. (2012), Dam and Scholtens (2012) or Fabrizi et al. (2013). EIRIS assigns grades on specific attributes in the different areas. This procedure involves some subjective assessment of relevant practices of the firms but the topics and questions are designed in a way to give a reasonable assessment of the relevant activities. CSR is broken down into a wide range of relevant activities or policies and each item is assigned a value between -3 and +3 . The first grade is major positive and has a value

\footnotetext{
${ }^{3}$ EIRIS is an independent research organization and a leading provider of non-financial information on companies' environmental, social and ethical policy and practice. It provides comprehensive research on over 3,000 companies globally. It offers consistent, comparable data on over 110 different ESG areas, including board practice, bribery and corruption, managing environmental and climate change impacts, human rights and supply chain labor standards - See more at: http://www.eiris.org/
} 
of 3 . The second is minor positive and has the value of 1 . On the contrary, major negative has a value of -3 and minor negative, of -1 . The EIRIS process starts with information disclosed by the companies. Then, targeted questionnaires are sent to companies regarding areas where public data are unclear. These results in considerable focused dialogue with companies that help clarify any concerns and refine their opinion. Sector specialists within each team review the research before the score is released.

The CSR score is determined from the equally-weighted sum of items classified under environmental issues, human rights, relations with stakeholders and board composition. The first of these areas concerns items such as the company’s environmental management system and policy, its impact on the environment, and whether the company has published reports on this. The second category is the general scope of the company's strategy, policy, systems and reporting in the field of human rights. The third group concerns the company's policy, management systems, quantitative information and level of commitment with stakeholders in general, policy and practices to support equal opportunities and diversity, health systems and safety at work procedures, support to employee training and development, relationships with customers and suppliers and the level of commitment with the community or social projects. Finally, in order to reflect the characteristics of the Board of Directors, the Board Index includes: (i) the independence of the Board, as determined by the separation of functions between the chief executive and the chairman, and the percentage of independent members on the Board and on the audit committee; (ii) the diversity of these two bodies in terms of the presence of women and representatives of different stakeholders; (iii) other transparency and control practices such as the existence of codes of ethics, policies to prevent bribery and corruption, and transparency regarding remunerations. Appendix 2 explains the composition of the CSR index in detail. 


\subsection{Institutional context variables}

Following Hillier et al. (2011), we use three sub-indices of investor protection that stem from the country-level governance indices of La Porta et al. (1998): (i) DCL, which equals 1 if the firm is located in a common law country and zero if the firm is located in a civil law country; (ii) DAR, which equals 1 if the firm is located in a country with more antidirector rights than the sample median, and zero otherwise; and (iii) DEF, which equals 1 if the firm is located in a country with a higher than median law enforcement index, and zero otherwise. Law enforcement is formed by two indices of La Porta et al. (1998): efficiency of the judicial system, and law and order. Finally, we proxy effective investor protection by summing the three dummy variables (DCL, DAR, and DEF). Based on this new variable measuring effective investor protection (the sum of DCL, DAR and DEF) which can take values between 0 and 3, we construct a new one, DINVPROTECTION. It equals 1 if the firm is located in a country with a higher than average effective investor protection, and zero otherwise. The countries with above average investor protection are Australia, Canada, Hong Kong, the United Kingdom and the United States.

In addition, and following Prado-Lorenzo and Garcia Sanchez (2010), we included another dummy variable based on the National Corporate Responsibility Index (NCRI), which identifies the aggregate institutional context for CSR and examines both the extent to which there is an enabling national environment for corporate responsibility, and the resulting outcomes of corporate responsibility in practice. This index is based on the weighted sum of seven components: corporate governance structures, ethical business practices, progressive policy formulation, building human capital, engagement with civil society, contributions to public finance and finally, environmental management. Each component is based upon a number of indicators and the basket of indicators is equally weighted, to give average scores 
from 0-100 for each component. Similarly, each of the seven components is equally weighted on the basis that they are all of equal importance to the development of a responsible economy. The results give an overall NCRI, again with a maximum possible score of 100 . For our purpose, our dummy variable, DNCRI, has the value of 1 if the company's country of origin has an above the average NCRI, and 0 otherwise. The countries with an above average NCRI are Australia, Canada, Denmark, Finland, Germany, Ireland, Luxembourg, the Netherlands, Norway, Sweden, Switzerland and the United Kingdom. .

\subsection{Control variables}

Cost of capital and corporate reputation depend on a number of firm characteristics and without them any analysis would suffer from omitted variable biases. We control for size, leverage, risk, operating liquidity, industry and R\&D intensity in our econometric models. Company size (SIZE) is measured by the logarithm of the total assets. In general, larger companies enjoy better reputation (Brammer and Pavelin, 2004) and a lower cost of capital (Hail and Leuz, 2006). This variable is widely used as a control variable in studies involving EM (without a consensus on its effect) and CSR studies (Prior et al., 2008). The level of firm leverage (DEBT) represents the debt or non-compliance risk (Prior et al., 2008; Surroca et al., 2010). Other things remaining equal, leverage leads to an increase of the cost of equity capital. RISK represents the level of systematic risk and is measured by the Beta of the market model. The CAPM suggests that systematic risk is priced and hence the beta risk is positively associated with the cost of capital. It is used by authors as Blanco et al. (2010) to determine its effect on the cost of capital. WORKINGCAPITAL is defined as the difference between current assets and current liabilities. It reflects liquidity, i.e. a company's ability to proceed normally with its activities in the short term. Companies with financial problems, 
which might be reflected as negative working capital and excess debt, may be more inclined to manipulate accounting numbers (Park and Shin, 2004). A large body of research shows that financial resources also have a strong positive association with CSR practices. Sector effect is captured using a set of categorical variables (INDUSTRY) based on the industry codes. According to Melo and Garrido-Morgado (2012), the impact of CSR on Corporate Reputation is moderated by the firm's industry. Moreover, it may affect its CSR practices (Chen and Bouvain, 2009). We have separate dummies for segments classed as Business materials, Consumer Discretionary, Consumer Staples products, Health Care, Industrial Field, Information Technology and Utilities. Finally, R\&DINTENSITY is measured by the ratio of R\&D expenditure to total revenue. Baber et al. (1991) and Dechow and Sloan (1991) among others show that companies that invest the most in R\&D have greater incentives toward EM, in order to achieve their goals project targets. On the other hand, McWilliams and Siegel (2001) point out that CSR is also dependent on R\&D costs. Firms that invest in R\&D create intangible assets which promote higher corporate reputation (Torres et al., 2012).

\subsection{Empirical Methodology}

The aim of this paper is to determine the effect of EM and CSR practices on the cost of capital and on corporate reputation, especially when CSR practices are carried out strategically to avoid negative reaction of the market and stakeholder groups to the managers’ result-based management. In the first set of models (model As), the dependent variable is the cost of capital $\left(\boldsymbol{r}_{\boldsymbol{P E G}}\right)$, and in the second set (model Bs), it is corporate reputation (REPUTATION). 
For the analyses of cost of capital we estimate Arellano and Bond (1991) simultaneous equations model for panel data using the generalised method of moments (GMM) method. It helps to address endogeneity problems that persist in least squares estimators. Following the argument of Wooldridge (2010), our tests could be biased due to endogeneity because, while the EM and CSR practices could partially explain $r_{P E G}$, expected cost of capital can influence the choice of EM and CSR. Estimation using instrumental variables models like the GMM can address this problem (Ogaki, 1993). Endogeneity problem can also be controlled using a simultaneous-equations estimator, such as maximum likelihood or two or three-stage least squares estimators, but the choice should be based on consistency (De Miguel et al., 2005). These methods are more efficient than GMM, but they are not consistent and generate biased results as they do not eliminate unobservable heterogeneity: firms' own specificity that gives rise to a particular behaviour. These differences between individuals are potentially correlated with the explanatory variables (also called individual specific effects like entrepreneurial skills, corporate culture, etc.), which are invariant over time and directly influence corporate decisions. In order to control unobservable heterogeneity, GMM decomposes the random error term $\left(\varepsilon_{\mathrm{i}}\right)$ into two parts: the combined effect $\left(\mu_{\mathrm{it}}\right)$, which varies depending on individuals and on time periods; and the individual effect $\left(\eta_{\mathrm{i}}\right)$, which is characteristic of the company.

We use Logit model for panel data in order to test our hypotheses about corporate reputation. As mentioned above, REPUTATION is a dummy variable taking the value of 1 if the company is listed in the World's most admired companies ranking, and of 0 if it is not. Given the categorical nature of the dependent variable, the best option is using nonlinear probability models, where a result between 0 and 1 is guaranteed for the estimation. 
First, we test $H 1 a$ and $H 1 b$ by running both sets of models with EM as the main variable of interest.

$r_{P E G} /$ REPUTATION $_{i t}=\varnothing_{1}$ EM $_{i t}+\emptyset_{2}$ Size $_{i t}+\emptyset_{3}$ Debt $_{i t}+\emptyset_{4}$ Risk $_{i t}+\varnothing 5$ Workingcapital $_{i t}+$ $\emptyset_{6}$ Industry $_{i t}+\varnothing_{7} R \& D$ Intensity $i t+\varepsilon_{i t}$

Then we focus on the effect of CSR practices on the cost of capital and on the company reputation ( $H 2 a$ and $H 2 b)$.

$r_{P E G} /$ REPUTATION ${ }_{i t}=\varnothing_{1}$ CSR $_{i t}+\varnothing_{2}$ Size $_{i t}+\varnothing_{3}$ Debt $_{i t}+\varnothing_{4}$ Risk $_{i t}+\varnothing$ Workingcapital $_{i t}+$ $\emptyset_{6}$ Industry $_{i t}+\emptyset_{7}$ R\&DIntensity ${ }_{i t}+\varepsilon_{i t}$

In order to test the shielding effect of CSR practices ( $H 3 a$ and $H 3 b)$, in we interact EM practices and CSR actions. So we have both CSR and EM practices and their interaction as independent variables in the models.

$r_{P E G} /$ REPUTATION $_{i t}=\emptyset_{1} E_{i t}+\emptyset_{2}$ CSRit $+\emptyset_{3} C S R^{*} E M_{i t}+\emptyset_{4}$ Size $_{i t}+\emptyset_{5}$ Debt $_{i t}+\emptyset_{6}$ Risk $_{i t}+$ $\varnothing_{7}$ Workingcapital $_{i t}+\varnothing_{8}$ Industry $_{i t}+\varnothing_{9} R \&$ DIntensity ${ }_{i t}+\varepsilon_{i t}$

In order to identify the institutional factors moderating the combined effect of CSR and EM on $r_{P E G}$ and REPUTATION (H4), we estimate two new models to determine the role of: (i) the national approach to CSR, and (ii) the level of investor protection in the firm's country of origin:

$r_{P E G} / R E P U T A T I O N_{i t}=\emptyset_{1} E M_{i t}+\emptyset_{2} C S R_{i t}+\emptyset_{3} C S R^{*} E M_{i t}+\emptyset_{4} C S R^{*} E M^{*} D N C R I_{i t}+\emptyset_{5} D N C R I_{i t}$ $+\emptyset_{6}$ Size $_{i t}+\varnothing_{7}$ Debt $_{i t}+\emptyset_{8}$ Risk $_{i t}+\emptyset_{9}$ Workingcapital $_{i t}+\emptyset_{10}$ Industry $_{i t}+\emptyset_{11}$ R\&DIntensity $_{i t}+\varepsilon_{i t}$ $[4 \mathrm{~A} / \mathrm{B}]$ 
$r_{P E G} / R E P U T A T I O N_{i t}=\emptyset_{1} E_{i t}+\emptyset_{2} C_{S R}+\emptyset_{3} C S R^{*} E M_{i t}+\emptyset_{4} C S R^{*} E M^{*} D_{I N V P R O T E C T I O N}$

$+\emptyset_{5}$ DINVPROTECTION $_{I t}+\varnothing_{6}$ Size $_{i t}+\emptyset_{7}$ Debt $_{i t}+\emptyset_{8}$ Risk $_{i t}+\varnothing_{9}$ Workingcapital $_{i t}+\emptyset_{10}$ Industry $_{i t}$

$+\varnothing_{11} R \&$ DIntensity ${ }_{i t}+\varepsilon_{i t}$

where:

$i$, represents the company and trepresents the time period.

ø, represents estimating parameters.

$\varepsilon_{\mathrm{it},}$ represents the error term.

$r_{P E G}$ is a continuous variable measured by the Cost of Capital.

REPUTATION is a dummy variable that represents whether the firm is one of the most admired companies worldwide or not.

$E M$ is a continuous variable that represents the accounting EM practices.

CSR is a continuous variable that reflects the CSR practices of the company.

$C S R^{*} E M$ is a continuous variable measured by the interaction between CSR and EM, that represents companies using CSR practices as an entrenchment strategy that conceals EM practices.

DNCRI and DINVPROTECTION are dummy variables that reflect the characteristics of the institutional and corporate contexts. These variables are analysed by their interaction with $C S R^{*} E M$.

SIZE is a continuous variable measured by the logarithm of the total assets.

$D E B T$ is a continuous variable measured as the ratio of debt to equity.

RISK is a continuous variable measured by the beta market.

WORKINGCAPITAL is a continuous variable measured by the difference between current assets and current liabilities.

INDUSTRY is a multinomial variable that represents the sector of activity. 
$R \& D I N T E N S I T Y$ is a continuous variable measured by the ratio of $\mathrm{R} \& \mathrm{D}$ expenditure to total revenue.

\section{RESULTS}

\subsection{Univariate analysis}

Table 1 shows the descriptive statistics of the variables used in this study. The mean value of cost of capital is of 1.88 basis points and its standard deviation, of \pm 2.26 basis points. The value is much smaller than expected because the expected earnings growth is exceptionally small in our sample period. Considering cost of capital as the minimum rate of return on equity investors for providing capital to the firm (Botosan, 2006), this mean value means that, on average, companies sample must provide to their shareholders at 1.88 basis point of return for their investments. Furthermore, its standard deviation of \pm 2.26 basis points means that this return on equity varies according to the risk-return principle (higher risk, higher demanded return). The mean value of the CSR variable is -22.74 (out of a possible range between -84 to +84$)$, implying that, on average, practices are not socially responsible. The standard deviation is of \pm 27.331 . Out of the four groups of CSR categories, the greatest concern in our sample of companies’ is board issues followed by environmental issues and human rights. The individual analysis of each item reveals that the most commonly implemented CSR practices concern relationships with customers and suppliers, and the use of environmental management systems. The companies in the sample have an average of 0.007 in EM. The proxy for EM is the discretionary accrual adjustments, which is the residual in the modified Jones model (Dechow et al., 1995) as explained in Appendix 1 and it can take positive or negative values. It is not surprising that the average is close to the ideal level of EM, which is zero implying that companies, on average, do not display significant EM practices. However, the relatively high standard deviation of 0.375 indicates 
that there is a wide variation EM practices in our sample. The mean values and standard deviations are very similar to those obtained in previous studies, such as Barton (2001), Prior et al. (2008) and Gray et al. (2009). The average SIZE of the analysed companies is 7.874 million Euros, with a standard deviation of \pm 1.979 million Euros. The average DEBT stands at 0.676 with a standard deviation of \pm 0.110 . Table 1 also shows the absolute and relative frequency of REPUTATION, a dummy variable with values between 0 and 1 . Only 645 companies (7.38\% of the sample) are listed in the World's most admired companies ranking, which is conceived as a reputation index in Fortune magazine.

\section{[Insert Table 1 around here]}

Table 2 shows the Pearson correlation coefficients between the different variables. The coefficients are not very high between the different independent variables indicating that there are no significant multicollinerity problems that might confound the estimation.

[Insert Table 2 around here]

Table 3 shows the mean values of CSR, EM and institutional factors per country. An individual analysis permit us observe the differences among countries. USA, with 2324 observations out of the total of 8786, is the most represented country in the sample, closely followed by Japan (with 1881 observations) and the United Kingdom (1634 observations). We note that Netherlands, Finland and France are the most socially responsible countries and Germany has the highest mean value of discretionary accruals. The table also indicates the group of countries with stronger commitment to CSR and investor protection.

[Insert Table 3 around here]

\subsection{Earnings Management, Corporate Social Responsibility and Cost of Capital.}

The empirical evidence reflecting the effect of EM, CSR and the entrenchment strategy on the cost of capital is shown in Table 4. Column 1 shows results for model $1 \mathrm{~A}$ and 
we find that the effect of EM on the cost of capital is positive and significant at $1 \%$ level which supports hypothesis H1a. Companies' engaging in EM practices is penalized by the market with a higher cost of capital. In column 2 (model 2A), CSR practices show a negative relationship with the cost of capital at a 5\% significance. This shows that companies that invest in CSR have lower costs of capital $(\mathrm{H} 2 a)$. Both results hold in the specification in the models presented in columns 3, 4 and 5. Both effects are economically significant. For example, from the coefficients in model 5 (A), we see that for an average firm, if EM becomes one standard deviation more aggressive, cost of capital increases by $17 \%$.

The shielding effect of CSR activities on the negative effect of EM (model 3A) is very significantly negative on the cost of capital (99\% confidence level). This suggests that investors get mixed signal when CSR is used along with EM and required cost of capital does not rise as sharply as a result of EM in these companies (H3A).

The effect of the interaction of EM, CSR and DNCRI, which reflects the effectiveness of shielding practices in countries with strong commitments to CSR, is positive and significant. Thus if investors and the market in general demand a strong commitment to CSR, trying to use CSR to shield EM can backfire and increase the cost of capital even more. Thus, hypothesis $H 4$ can be accepted. The result of the interaction of EM, CSR and DINVPROTECTION (model 5A,column 5) is negative and significant Therefore, managers use CSR practices as a means of disguising EM successfully when they work in companies operating in contexts where investor interests and rights tend to be more protected by law.

\section{[Insert Table 4 around here]}

Observing the coefficient of the control variables, the very significant negative effect of the company size stands out. This indicates that investors of big companies demand lower cost of capital for their investments. WORKINGCAPITAL has a positive effect on the 
dependent variable of model A when the effect of EM and CSR in the cost of capital is individually analyzed. However, the coefficient of the interaction of the shielding effect and investor protection is negative implying that the shielding effect is weaker in countries with strong investor protection. The other variables mostly show expected signs, but are not significant in the majority of the models.

\subsection{Earnings Management, Corporate Social Responsibility and Corporate}

\section{Reputation.}

Table 5 shows the results of the Logit models designed to capture the effect of EM, CSR and shielding strategy on corporate reputation. The link between EM practices and reputation (model 1B) is negative and highly significant supporting $H 1 B$. We obtain exactly opposite sign (at 1\% significance) when analyzing the consequences of CSR practices on reputation. Therefore, we can accept hypothesis H2b. The negative link between EM and reputation and the positive one between CSR and reputation are present in the rest of models (2B, 3B, 4B and $5 B$ ). We find that the interaction term $\mathrm{EM}^{*} \mathrm{CSR}$ is insignificantly different from zero, implying that positive CSR strategies in itself improves reputation, but it does not help reclaim additional ground lost to firms that display EM practices. Therefore, hypothesis H3b is not supported by the data. In addition, interest groups lightly punish shielding practices when implemented in contexts strongly committed with CSR (model 4B) and in countries with weak protection of investors' interests and rights (model 5B). The control variables show patterns that are similar to the previous table as we observe that reputation is significantly higher for bigger companies and companies with higher levels of working capital. 
[Insert Table 5 around here]

\subsection{Robustness tests}

We estimate the models (cost of capital and reputation) after partitioning the full sample into two groups based on whether the firms are based in a common law or a civil law country. We observe that $46.67 \%$ of observations belong to a civil law country. Table 6 shows the effect of EM, CSR, and entrenchment for the subsample of civil or common law countries separately. In both institutional contexts EM result in significantly higher cost of capital, while CSR strategy generates a decrease in it. But the direct effect of CSR is only significant in the case of civil law countries. The most significant difference between the results in the two samples is seen in the shielding effect of EM. Strategic use of CSR to shield the effect of EM seems to work well in common law countries, but backfires in civil law countries. The results of the model for corporate reputation shows similar pattern, but the significance is completely lost except for the direct impact of CSR and EM in common law countries.

[Insert Table 6 around here]

\subsection{Discussion of the overall picture from the results}

We show that cost of capital can be influenced by financial and strategic decisions, a result consistent with Dhaliwal et al. (2011). Market risk and uncertainty stemming from mistrust towards companies that manipulate their results leads to a higher required rate of return. Companies with a greater level of discretionary management of accruals face higher costs of capital, ceteris paribus. We also show that investors require a lower return if companies promote CSR practices, a result consistent with the findings by El Ghoul et al. (2010) and Gregory et al. (2011). These companies are considered to have a long term plan in 
developing loyalty and community relationship and are considered as financially more stable and less vulnerable to activism. We also demonstrate that CSR can be strategically used by managers to lower the negative impact of questionable accounting practices and protect themselves against big rise in cost of capital and fall in reputation, a result comparable to the effectiveness of social policies in the context of marketing (Handelman and Arnold, 1999). Our results showing that EM practices have a negative effect on corporate reputation are consistent with previous evidence by Fombrun et al. (2000) and Roychowdhury (2006) among others. The market and other stakeholders negatively value managers who carry out aggressive accounting practices for short term personal gains against the interest of shareholders, investors and non financial stakeholders. These discretionary practices cause the loss of support from the affected stakeholders and increase their activism (Zahra et al., 2005).

On the other hand, a well rounded CSR strategy helps to improve the perception of shareholders, banks, regulation agencies, customers, suppliers, media and the community and we show that this is reflected in corporate reputation and financing costs. We also find that CSR can help firms recover credibility lost through EM practices. When combined with CSR, EM practices are ignored, or not punished significantly, by the investors and the non financial stakeholders. This strikes a chord with Prior et al. (2008) and Gargouri et al. (2010), who point out that CSR improves a company’s corporate image irrespective of the ultimate goal pursued by the managers. The validity and consistency of CSR scores, widely used in the ethical investments sector and academic research, is a hotly contested issue. Delmas et al. (2013) and Chatterji et al. (2014) finds a lack of consistency among CSR scores provided by different organizations covering US companies and point out the lack of transparency in the evaluation process and the dangers in putting too much trust in any one of them. Our results are based on the most widely used measure of CSR covering a large 
number of international companies and we agree that our measure of CSR also suffer from the same caveat. But as long as markets fixate on widely used CSR scores as a measure of business ethics and sustainable practices, corporations might be able to use these very noisy and questionable scores as a tool to generate positive sentiments from ethical investors and loyalty from stakeholders. Institutional context (national commitment to CSR and the level of investor protection in the company's country of origin) plays an important role to moderate the relationship between, EM, CSR and cost of capital (corporate reputation). These results support previous evidence by Scholtens and Kang (2012) and Leuz et al. (2003).

\section{Concluding remarks}

In recent years, accounting practices and ethical standards of companies are scrutinized intensely by investors and non-financial stakeholders. Investments in CSR can give competitive advantage in the product market and, in general, can signal a company's healthy long-term outlook. But does it provide managers with an opportunity to use CSR practices for significant improvement in the corporate image? We show that CSR can be used to shield the negative effect of discretionary accounting practices on cost of capital. Corporations not only obtain direct economic and financial benefits from implementation of CSR policies, it also helps to cover up for EM practices. The markets cannot identify situations when CSR policies have a higher probability of being used as a short term strategy to improve corporate image. They have a negative effect on cost of capital by itself and they also reduce the rise in cost to companies that simultaneously engage in EM. We also find that the favorable effect of CSR is more pronounced in countries with strong investor protection. The shielding effect does not work in countries that have strong commitment to CSR and it is expected. A more thorough country and institution specific analysis needs to be done to understand how the relevant policies influence corporate strategies. 
The results on corporate reputation are similar to the findings on the direct effect of EM and CSR on cost of capital. The stakeholders identify aggressive accounting practices and the reputation of these companies takes a hit as a result. However, companies that promote responsibility to social and environmental causes strongly have higher reputation. These companies are more likely to be listed among the world's most admired companies. But the market is more conservative in their assessment of CSR in countries with strong investor protection and an environment of higher commitment to CSR and possibly takes account that companies might try to use CSR policies primarily to hide their EM. We partition the sample into civil and common law countries to re-iterate how the effect of CSR and EM can be influenced by the legal environment in which the company operates.

Our findings contribute to the emerging literature attempting to understand the motivation of discretionary practices by managers. The highlight of the paper is the result that mangers might be able to shield their companies from punishment for EM practices by projecting their CSR policies. This is consistent with the Legitimacy Theory and the Stakeholder theory which explain how businesses can benefit by aligning with values constructed by the society. In this situation, managers may attempt to manipulate the perception about their image using CSR strategies at the margin and future research should try to identify if some groups of firms have an insincere box-ticking CSR strategy while others seem to show real commitment. We show that the positive effects of CSR not only affects long term loyalty of stakeholders through reputation, it brings home benefits instantly in the shape of lower cost of capital, and company insiders and large shareholders should aim to design compensation contract for executives that encourage them to invest in CSR. This basic result can help investors, stakeholders and regulatory authorities evaluate the implications of EM and CSR practices being carried out concurrently and inform them of the possibility that CSR can be used to shield negative perception about the company. In 
particular, they should demand higher levels of transparency and accountability and look beyond the reductionist measures of CSR and sustainability. The different measures themselves show a significant variability among themselves and they can be used to manipulate perception, confuse and misinform while the real concerns on sustainability and ecology takes a back seat in corporate strategy (Milne and Gray, 2013). This paper shows evidence of such strategies and as pointed out by Buhr et al. (2014), more research should be done to understand managerial priorities in their CSR strategies and snowball big reforms in corporate behavior. 


\section{APPENDIX 1: Measuring Earnings Management with Discretionary Accruals}

\section{Jones' standard model}

Following Jones (1991) and Dechow et al. (1995), total accrual adjustments (TAA) are defined as:

$$
T A A_{i t}=\left[\left(\Delta C A_{i t}\right)-\left(\Delta C A S H_{i t}\right)\right]-\left[\left(\Delta C L_{i t}\right)-\left(\Delta R L T P_{i t}\right)\right]-D A_{i t}
$$

where $\Delta \mathrm{CA}_{\mathrm{it}}$ represents the change in current assets; $\Delta \mathrm{CASH}_{\mathrm{it}}$ reflects the change in cash held and in shortterm financial investments; $\Delta \mathrm{CL}_{\text {it }}$ is the change in current liabilities; $\Delta \mathrm{RLTP}$ it is the change in reclassified long term obligations; $\mathrm{DA}_{\mathrm{it}}$ is the depreciation and amortization; i represents the company; and t represents the year.

On the basis of equation (a.1), accruals are calculated using an explanatory model. The difference between actual and expected accrual adjustments (taking into account growth, company assets and the accounting result) represents the discretionary or unexplained component of accrual adjustments (DAA). It acts as a measurement of management discretion in the reporting of results.

The standard Jones model uses the following procedure to separate the discretionary component and the non-discretionary one:

$\frac{T A A_{i t}}{A_{i, t-1}}=\alpha_{1, t}\left(\frac{1}{A_{i, t-1}}\right)+\alpha_{2, t}\left(\frac{\Delta \text { Sales }_{i t}}{A_{i, t-1}}\right)+\alpha_{3, t}\left(\frac{P P E_{i t}}{A_{i, t-1}}\right)+\varepsilon_{t}$

where $\frac{T A A_{i t}}{A_{i, t-1}}$ are the total accrual adjustments; $A_{i, t-1}$ represents the total assets of firm $i$ in period $t-1$ (this is used as a deflator to correct possible problems of heteroscedasticity); $P P E_{i t}$ represents the property, plant and equipment of firm $i$ in period $t$; and $\Delta$ Sales $_{i t}$ is the change in sales for firm $i$ in period $t$.

The non-discretionary accrual adjustments (NDAA) are $\alpha_{1, t}\left(\frac{1}{A_{i, t-1}}\right)+\alpha_{2, t}\left(\frac{\Delta \text { Sales }_{i t}}{A_{i, t-1}}\right)+\alpha_{3, t}\left(\frac{P P E_{i t}}{A_{i, t-1}}\right)$, and $\varepsilon_{t}$ represents the discretionary accrual adjustments (DAA) for firm $i$ in year $t$. NDAA are calculated by replacing the coefficients in equation (a.2) with the values obtained by Ordinary Least Squares. DAA are the residuals of this calculation.

\section{Modified Jones model (Dechow et al., 1995)}

In the modified Jones model (Dechow et al., 1995, equation a.3), the TAA use the variation in sales minus accounts receivable (used to measure the company's growth, because its working capital is closely linked to sales) and minus the item property, plant and equipment (used to measure the depreciation costs of the discretionary adjustments). It is assumed that not all sales are necessarily non-discretionary, and that this will depend on the item to be received.

$\frac{T A A_{i t}}{A_{i, t-1}}=\alpha_{1, t}\left(\frac{1}{A_{i, t-1}}\right)+\alpha_{2, t}\left(\frac{\Delta(\text { Sales }-A * R)_{i t}}{A_{i, t-1}}\right)+\alpha_{3, t}\left(\frac{P P E_{i t}}{A_{i, t-1}}\right)+\varepsilon_{t}$

where $A * R$ represents accounts receivable, and the other variables are defined as in equation (a.2).

Please note that coefficients in this model are calculated using the original Jones model (1991), and the modification is only applied when calculating non-discretionary adjustments. 


\section{APPENDIX 2: Corporate Social Responsibility}

Figure 1 represents the composition of the CSR index, and analyzes several areas (environment, human rights, the relationships with stakeholders and board of directors).

\begin{tabular}{|c|}
\hline Figure 1. CSR PRACTICES \\
\hline ENVIRONMENTAL INDEX \\
\hline Environmental policies and commitment \\
\hline Environmental management systems \\
\hline Environmental reporting \\
\hline Level of environmental impact improvement \\
\hline HUMAN RIGHTS INDEX \\
\hline Extent of policies addressing human rights issues \\
\hline Extent of systems addressing human rights issues \\
\hline Extent of reporting addressing human rights issues \\
\hline STAKEHOLDER INDEX \\
\hline Policies towards stakeholders overall \\
\hline Management systems for stakeholders overall \\
\hline Quantitative reporting for stakeholders overall \\
\hline Level of engagement with stakeholders overall \\
\hline Policies on equal opportunities and diversity issues \\
\hline Systems and practices to support equal opportunities and diversity issues \\
\hline Health \& Safety systems \\
\hline Systems and practices to advance job creation and security \\
\hline Systems to manage employee relations \\
\hline Systems to support employee training and development \\
\hline Policies on maintaining good relations with customers - suppliers \\
\hline Systems to maintain good relations with customers - suppliers \\
\hline Level of commitment with community or charitable work \\
\hline BOARD INDEX \\
\hline The company separates the roles of the Chairman and the Chief Executive \\
\hline The proportion of independent non-executive directors exceeds 33\% \\
\hline The company has an audit committee with a majority of independent non-executive directors \\
\hline Level of stakeholder issues allocated to members \\
\hline Gender diversity in the boardroom \\
\hline Policies and procedures on bribery and corruption (policies, system and reporting) \\
\hline Level of comprehension of the code of ethics \\
\hline The company discloses the remuneration of its directors \\
\hline
\end{tabular}




\section{REFERENCES}

Arellano, M., and Bond, S. 1991. Some tests of specification for panel data: Monte Carlo evidence and an application to employment equations. The Review of Economic Studies 58(2), 277-297.

Bakan, J. (2005). The corporation: The pathological pursuit of profit and power. (Vancouver: Simon and Schuster).

Banerjee S.B. (2007) Corporate social responsibility: The good, the bad and the ugly (Cheltenham: Edward Elgar).

Banerjee, S., Dasgupta, S., Kim, Y., 2008. Buyer-supplier relationships and the stakeholder theory of capital structure. Journal of Finance 63, 2507-2552.

Barnett, M. L. 2007 . Stakeholder influence capacity and the variability of financial returns to corporate social responsibility. The Academy of Management Review 32(3), 794-816.

Barney J. 1991. Firm resources and sustained competitive advantage. Journal of Management 17: 99-120.

Barton, J. 2001. Does the use of financial derivatives affect earnings management decisions?. The Accounting Review, 76(1), 1-26.

Basu, K. and Palazzo. 2008 . Corporate Social Responsibility: A Process Model of Sense making. Academy of Management Review, 33 (1), 122-136.

Bhattacharya, U., Daouk H. and Welker M. 2003 . The World Price of Earnings Opacity. Accounting Review $78,641-678$.

Blanco, B., García, J.M. and Tribó, J.A. 2009 . The complementary between segment disclosure and earnings quality, and its effect on cost of capital. 32 nd Annual Congress of the European Accounting Association.

Botosan, C. A., and Plumlee, M. A. 2005 . Assessing alternative proxies for the expected risk premium. The Accounting Review 80, 21-53.

Botosan, C.A. 2006. Disclosure and the cost of capital: what do we know? Accounting and Business Research, International Accounting Policy Forum, 31-40.

Brammer, S. J., Brooks, C. and S. Pavelin 2006. Corporate social performance and stock returns: UK evidence from disaggregate measures”, Financial Management, 97-116.

Brammer, S. and Pavelin, S. 2004 . Building a Good Reputation. European Management Journal. 22 (6), 704713.

Branco MC. and Rodrigues, LL. 2006 . Corporate social responsibility and resource - based perspectives. Journal of Business Ethics, 69, 111-132. 
Buhr, N, Gray, R and Milne, M.J., (2014) Histories, rationales and future prospects for sustainability reporting, Chapter 4 in Sustainability Accounting and Accountability, Unerman, J, Bebbington, J. and O’Dwyer, B. (eds.), 2nd Edition, Routledge.

Carroll, A. B. 1979. A three-dimensional conceptual model of corporate performance. Academy of Management Review, 4(4), 497-505.

Cespa, G., and Cestone, G. 2007. Corporate social responsibility and managerial entrenchment. Journal of Economics \& Management Strategy,16(3), 741-771.

Chand, M. 2006 . The Relationship Between Corporate Social Performance and Corporate Financial Performance: Industry Type as a Boundary Condition.The Business Review,5(1), 240-245.

Chatterji, A. K., Durand, R., Levine, D. \& Touboul, S.. (2014). Do Ratings of Firms Converge? Implications for Strategy Research. IRLE Working Paper No. 107-14.

Chatterji, A. K., Levine, D. I., and Toffel, M. W. (2009). How well do social ratings actually measure corporate social responsibility?. Journal of Economics \& Management Strategy, 18(1), 125-169.Chen, C., Lin, C., and Lin, Y. 2008 . Audit partner tenure, audit firm tenure, and discretionary accruals: Does long auditor tenure impair earnings quality? Contemporary Accounting Research, 25 (2),447-471.

Chen, S. and Bouvian, P. 2009 . Is Corporate Social Responsibilty Converging? A comparison of Corporate Social Responsibility Reporting in the USA, UK, Australia and Germany. Journal of Business Ethics, 87, 299-317.

Chih, H. L., Shen, C.H. and Kang, F.C. 2008 . Corporate social responsibility, investor protection, and earnings management: Some international evidence. Journal of Business Ethics 79(1), 179-198.

Cohen, D. A. and Zarowin, P. 2010 . Accrual-based and real earnings management activities around seasoned equity offerings. Journal of Accounting and Economics, 50 (1), 2-19.

Dam, L., and Scholtens, B. 2012b. Ownership Concentration and CSR Policy of European Multinational Enterprises. Journal of Business Ethics, 1-10.

Dhaliwal, D., Li, O., Tsang, A. and Yang, Y. 2011 . Voluntary non-financial disclosure and the cost of equity capital: The initiation of corporate social responsibility reporting. The Accounting Review, 86 (1), 59-100.

Dechow, P. M. Sloan, R. G. and Sweeney, A. P. 1995. Detecting earnings management. Accounting Review, 70(2), 193-225.

Dechow, P. M., S. Kothari, and R. Watts. 1998 . The relation between earnings and cash flows. Journal of Accounting and Economics, 25 (2), 133-168 
de Miguel, A., Pindado, J. and de la Torre, C. 2005 . How do entrenchment and expropriation phenomena affect control mechanisms? Corporate Governance: An International Review 13, 505-516.

Delmas, M., Etzion, D., \& Nairn-Birch, N. (2013). Triangulating Environmental Performance: What Do Corporate Social Responsibility Ratings Really Capture?. The Academy of Management Perspectives, amp-2012.

Donaldson, T. and Preston, L. E. 1995 . The stakeholder theory of the corporation: Concepts, evidence and implications. Academy of Management Review 20, 65-91.

El Ghoul, S., Guedhami, O., Kwok, C.C.Y. and Mishra, D. 2011 . Does Corporate Social Responsibility affect the cost of capital? Journal of Banking and Finance, 35 (9), 2388-24060.

Entine, J. (2003). The myth of social investing. Organization \& Environment, 16(3), 352-368.

Fabrizi, M., Mallin, C., and Michelon, G. 2013. The Role of CEO’s Personal Incentives in Driving Corporate Social Responsibility. Journal of Business Ethics, 1-16.

Ferrer, A. and Quintanilla, J. 1998 . Multinationals, national identity, and the management of HRM: AngloSaxonisation and its limits. International Journal of Human Resource Management, 9 (4), 710-731

Fombrun, C. 1996. Reputation: Realising Value from the Corporate Image. Harvard Business School Press, Harvard, MA.

Fombrun, C. and Shanley, M. 1990 . What's the name? Reputation building and corporate strategy. Academy of Management Journal, 33, 233-258.

Fombrun, C. J., Gardberg, N. A. and Barnett, M. L. 2000 . Opportunity platforms and safety nets: Corporate citizenship and reputational risk. Business and Society Review 105(1), 85-106.

Francis, J., LaFond, R., Olsson, P. and Schipper, K. 2004 . Costs of equity and earnings attributes. The Accounting Review, 79 (4), 967-1000.

Francis, J., LaFond, R., Olsson, P. and Schipper, K. 2005 . The market pricing of accruals quality. Journal of Accounting and Economics 39, 295-327.

Francis, J., Nanda, D.J. and Olsson, P., 2008a . Voluntary Disclosure, Earnings Quality, and Costs of Capital. Journal of Accounting Research 46, 53-99.

Francis, J., Huang, A. H., Rajgopal, S. and Zang, A. 2008b. CEO Reputation and Earnings Quality. Contemporary Accounting Research, 25 (1), 109-147.

Gargouri, R. M., Shabou, R. and Francoeur, C. 2010 . The relationship between corporate social performance and earnings management. Canadian Journal of Administrative Sciences/Revue Canadienne Des Sciences 
De l'Administration 27(4), 320-334.

Gray, P., Koh, P. and Tong, Y. 2009 . Accruals quality, information risk and cost of capital: Evidence from Australia. Journal of Business Finance and Accounting 36, 51-72.

Gray, R. (2006). Social, environmental and sustainability reporting and organisational value creation?: Whose value? Whose creation?. Accounting, Auditing \& Accountability Journal, 19(6), 793-819.

Gray, R. H., Kouhy, R. and Lavers, S. 1995 . Methodological themes: constructing a research database of social and environmental reporting by UK companies. Accounting, Auditing and Accountability Journal, 8(2), 78-101.

Greene, W. H. 2003 . Econometric Analysis. Prentice Hall. New Jersey, USA.

Gregory, A, Tharyan, R and Whittaker, J. 2011 . Corporate Social Responsibility and the Valuation of Firms. *Xfi Centre for Finance and Investment, University of Exeter, UK.

Hawken, P. (2004). Socially responsible investing. How the SRI industry has failed to respond to people who want to invest with conscience and what can be done to change it. Natural Capital Institute, Sausalito.

Haigh, M. (2006b). Camouflage play: Making moral claims in managed investments. Accounting Forum (Vol. 30, No. 3, pp. 267-283).

Hail, L. and Leuz, C. 2006 . International differences in cost of equity capital: Do legal institutions an securities regulations matter? Journal of Accounting Research, 44, 485-531.

Handelman J.M. and Arnold S.J. 1999 . The role of marketing actions with a social dimension: Appeals to the institutional environment. Journal of Marketing 63(3), 33-48.

Haw, I., Hu, B., Hwang, L. and Wu, W. 2004 . Ultimate ownership, income management, and legal and extralegal institutions. Journal of Accounting Research 42 (2), 423-462.

Healy, P., and Wahlen, J. 1999 . A review of the earnings management literature and its implications for standard setting. Paper prepared for discussion at the 1998 AAA/FASB Financial Reporting Issues Conference, Accounting Horizons 13, 365-383.

Hong. Y. and M. L. Andersen. (2011). The relationship between corporate social responsibility and earnings management: an exploratory study. Journal of Business Ethics, 104 (4): 461-471.

Jensen, M. and Ruback, R. 1983. The market for corporate control: The scientific evidence. Journal of Financial Economics, 11:. 5-50

Kim, Y., Park, M. S. and Wier, B. 2012 . Is earnings quality associated with corporate social responsibility? Accounting Review, Forthcoming.Available at SSRN: http://ssrn.com/abstract=1899071 
Kolk, A., and Perego, P. 2008 . Determinants of the adoption of sustainability assurance statements: An international investigation. Business Strategy and the Environment 19(3), 182-198

Lai, C., Chiu, C., Yang, C., and Pai, D. 2010 . The effects of corporate social responsibility on brand performance: The mediating effect of industrial brand equity and corporate reputation. Journal of Business Ethics, 95 (3), 457-469.

Lambert, R., Leuz, C. and Verrecchia, R. 2007 . Accounting information, disclosure, and the cost of capital. Journal of Accounting Research 45, 385-420.

La Porta, R., Lopez-de-Silane, F., Shleifer, A. and Vishny, R. W. 1998. Law and Finance. Journal of Political Economy 106(6), 1113-1155.

La Porta, R., Lopez-de-Silane, F., and Shleifer, A. 1999. Corporate ownership around the world. Journal of Finance 54, 471-517.

La Porta, R., Lopez-de-Silane, F., Shleifer, A. and Vishny, R. W. 2000. Investor Protection and Corporate Governance. Journal of Financial Economics 58, 3-27.

Larcker, D. F., and Rusticus, T.O. 2010. On the use of instrumental variables in accounting research, Journal of Accounting and Economics, 49 (3) , 186-205.

Lefort, F. and González, R. 2008. Hacia un mejor gobierno corporativo en Chile. Abante, 11(1), 17-37.

Leuz, C., Nanda, D., and P. D. Wysocki. 2003. Earnings management and investor protection: An international comparison. Journal of Financial Economics 69(3), 505-527

Louche, C., Arenas, D., and van Cranenburgh, K. C. 2012. From preaching to investing: Attitudes of religious organisations towards responsible investment. Journal of business ethics, 110(3), 301-320.

Lu, H., Richardson, G. and Salterio, S. 2011. Direct and Indirect Effects of Internal Control Weakness on Accrual Quality: Evidence from a Unique Canadian Regulatory Setting. Contemporary Accounting Research, 28 (2), 675-707.

Marginson, P. and Sisson, K. 1994. The Structure of Transnational Capital in Europe: The Emerging EuroCompany and its Implications for Industrial Relations. In Hyman, R. and Ferner, A. (eds) New Frontiers in European Industrial Relations. Oxford, Blackwell

McWilliams, A. and Siegel, D. S. 2001 . Corporate social responsibility: A theory of the firma perspective. Academy of Management Review, 26(1), 117-127.

McWilliams, A., Siegel, D. S. and Wright, P. M. 2006 . Corporate social responsibility: Strategic Implications. Journal of Management Studies, 43 (1), 1-18. 
Melo, T. and Garrido-Morgado, A. 2012 . Corporate Reputation: A combination of Social Responsibility and Industry. Corporate Social Responsibility and Environment Management, 19, 11-31.

Milne, M.J., (2013) Phantasmagoria, Sustain-a-Babbling and the Communication of Corporate Social and Environmental Accountability, Chapter 14 in The Routledge Companion to Accounting Communication, Craig, R and Davison, J (eds.), Routledge.

Ogaki, M. 1993 . 17 Generalized method of moments. Econometric applications, Handbook of Statistics, Elsevier, 11, 455-488.

Ohlson, J., and B. Juettner-Nauroth. 2003. Expected EPS and EPS growth as determinants of value. Working paper, New York University.

Pindado, J. and Requejo, I. 2012 . Panel data: a methodology for model specification and testing, Finance volume of Wiley Encyclopedia of Management, (in press).

Post, J. E., Preston, L., and Sachs, S. 2002 . Managing the Extended Enterprise: The New Stakeholder View. California Management Review, 45 (1), 6-29.

Prado-Lorenzo, J. M., and Garcia-Sanchez, I.M. 2010 . The role of the board of directors in disseminating relevant information on greenhouse gases. Journal of Business Ethics 97(3), 391-424.

Prado-Lorenzo, J. M., García-Sánchez, I. M. and Gallego-Álvarez, I. 2012 . Effects of Activist shareholding on corporate social responsibility reporting Practices: an empirical study in Spain. Journal of Economics, Finance and Administrative Science, 17 (32), 7-16.

Prior, D., Surroca, J., and J. A. Tribó. 2008 . Are socially responsible managers really ethical? Exploring the relationship between earnings management and corporate social responsibility. Corporate Governance: An International Review 16(3), 160-177.

Roychowdhury, S. 2006 . Earnings Management through real activities manipulation. Journal of Accounting and Economics, 42 (3), 335-370.

Scholtens, B., and Dam, L. 2007. Cultural values and international differences in business ethics. Journal of Business Ethics, 75(3), 273-284.

Scholtens, B. and Kang, F. C. 2012 . Corporate Social Responsibility and Earnings Management: Evidence from Asian Economies. Corporate Social Responsibility and Environmental Management. Article first published online 9-03-2012. http://dx.doi.org/10.1002/csr.1286.

Sen, S., and Bhattacharya, C. B. (2001 . Does doing good always lead to doing better? Consumer reactions to Corporate Social Responsibility. Journal of Marketing Research, 38, 25-243. 
Sen, S., Bhattacharya, C. B., and Korschun, D. 2006 . The role of corporate social responsibility in strengthening multiple stakeholder relationships: A field experiment. Journal of the Academy of Marketing Science, 34(2), 158-166.

Shleifer, A., and Vishny, R. W. 1997 . A survey of corporate governance. The Journal of Finance, 52(2), 737783.

Simnett, R., Vanstraelen, A. and Chua, W.F.. 2009. Assurance on sustainability reports: An international comparison. The Accounting Review, 84 (3), 937-967.

Surroca, J., Tribó, J. A. and Waddock, S. 2010 . Corporate responsibility and financial performance: the role of intangible resources.Strategic Management Journal, 31 (5), 463-490.

Titman S. 1984.The effect of capital structure on a firm's liquidation decision. Journal of Financial Economics, 3(1), 137-151.

Torres, A., Bujmolt, T., Tribó, J. and Verhoel, P. 2012 . Generating global brand equity through corporate social responsibility to key stakeholders. International Journal of Research in Marketing, 29 (1), 13-24.

Van Tulder, R., and Van der Zwart, A. 2006 . International business-society management: linking corporate responsibility and globalization. Psychology Press.

Williams, R.J. and Barrett, J.D. 2000 . Corporate philanthropy, criminal activity, and firm reputation: Is there a link. Journal of Business Ethics 26, 341-350.

Williams, M.S. and Wern Pei, C.H. 1999 . Corporate social disclosures by listed companies on their web sites: An international comparison. The International Journal of Accounting, 34 (3), 389-419.

Wooldridge, J. M. 2010 . Econometric Analysis of Cross Section and Panel Data, (2nd Edition), MT Press.

Zahra, S. A., Priem, R. L. and Rasheed, A. A. 2005 . The antecedents and consequences of top management fraud. Journal of Management 31(6), 803-828.

Zang, A. 2012 . Evidence on the tradeoff between real manipulation and accrual manipulation. The Accounting Review, 87 (2), 675-703. 


\begin{tabular}{|c|c|c|}
\hline \multicolumn{3}{|c|}{ Table 1. Descriptive Statistics } \\
\hline & Mean & Std. Dev. \\
\hline $\mathbf{r}_{\text {PEG }}$ & 0.0188 & 0.0226 \\
\hline CSR & -22.74 & 27.331 \\
\hline ENVIRONMENTAL INDEX & -2.53 & 7.875 \\
\hline HUMAN RIGHTS INDEX & -7.19 & 3.770 \\
\hline STAKEHOLDER INDEX & -13.02 & 18.891 \\
\hline BOARD INDEX & 2.52 & 9.640 \\
\hline $\begin{array}{l}\mathbf{E M} \\
\end{array}$ & 0.007 & 0.375 \\
\hline SIZE & 7.874 & 1.979 \\
\hline DEBT & 0.676 & 0.110 \\
\hline RISK & 1.212 & 8.265 \\
\hline WORKING CAPITAL & 627.449 & 2840.651 \\
\hline INDUSTRY & 2.894 & 1.703 \\
\hline R\&D INTENSITY & 0.179 & 4.909 \\
\hline REPUTATION & \multicolumn{2}{|c|}{645 firm years ( $7.38 \%$ are World’s most admired) } \\
\hline Sample & \multicolumn{2}{|c|}{8785 observations, 2006-010, 26 countries } \\
\hline $\begin{array}{l}r_{P E G} \text { represents the implied cost } \\
\text { Management practices measured by } \\
\text { period t. Size represents the size of } \\
\text { debt of the company and is calculate } \\
\text { Working_Capital represents liquid } \\
\text { Industry represents the economic } \\
\text { expenditure in comparison with th } \\
\text { company is one of the most admire }\end{array}$ & $\begin{array}{l}\text { ed by the model by Ec } \\
\text { (1995) model. CSR sh } \\
\text { is measured by the log } \\
\text { ebt to equity. Risk repre } \\
\text { the difference betwee } \\
\text { mpany. R\&DIntensity } \\
\text { EPUTATION is a dum } \\
\text { n not. }\end{array}$ & $\begin{array}{l}\text { resents the Earnings } \\
\text { ices of company i for } \\
\text { ssets. Debt shows the } \\
\text { measured by the beta. } \\
\text { d current liabilities. } \\
\text { showing the R\&D } \\
\text { presents whether the }\end{array}$ \\
\hline
\end{tabular}


Table 2. Pairwise Correlations

\begin{tabular}{|c|c|c|c|c|c|c|c|c|c|c|c|}
\hline & 1 & 2 & 3 & 4 & 5 & 6 & 7 & 8 & 9 & 10 & 11 \\
\hline 1. $r_{P E G}$ & 1 & & & & & & & & & & \\
\hline 2. REPUTATION & -0.008 & 1 & & & & & & & & & \\
\hline 3. EM & -0.074 & 0.035 & 1 & & & & & & & & \\
\hline 4. $C S R$ & -0.296 & 0.156 & 0.192 & 1 & & & & & & & \\
\hline 5. DNCRI & 0.081 & -0.010 & -0.028 & -0.205 & 1 & & & & & & \\
\hline 6. DINVPROTECTION & 0.020 & -0.089 & -0.023 & -0.110 & 0.040 & 1 & & & & & \\
\hline 7. Size & -0.421 & 0.228 & 0.059 & 0.393 & -0.371 & -0.042 & 1 & & & & \\
\hline 8. Debt & -0.020 & 0.117 & -0.020 & -0.049 & 0.001 & -0.008 & 0.035 & 1 & & & \\
\hline 9. Risk & 0.005 & -0.027 & -0.001 & 0.120 & 0.171 & 0.118 & 0.056 & 0.004 & 1 & & \\
\hline 10. Working_capital & -0.195 & 0.192 & 0.086 & 0.270 & -0.131 & 0.052 & 0.192 & 0.049 & 0.088 & 1 & \\
\hline 11. R\&DIntensity & 0.044 & -0.106 & 0.019 & 0.114 & 0.020 & 0.079 & 0.127 & 0.052 & -0.079 & 0.009 & 1 \\
\hline
\end{tabular}

$\boldsymbol{r}_{\boldsymbol{P E G}}$ represents the implied cost of capital measured by the model by Easton (2004). REPUTATION is a dummy variable that represents whether the company is one of the most admired ones worldwide or not. EM represents the Earnings Management practices measured by the Dechow et al. (1995) model. CSR shows the CSR score of company i for period t. Size represents the size of the company and is measured by the logarithm of its total assets. Debt shows the debt of the company and is calculated as the ratio of debt to equity. Risk represents the faced risk measured by the beta. Working_Capital represents liquidity, measured as the difference between current assets and current liabilities. R\&DIntensity represents the ratio showing the R\&D expenditure in comparison with the total of sales. 
Table 3. Descriptive Statistics per country

\begin{tabular}{|c|c|c|c|c|c|}
\hline & Observations & CSR & $E M$ & DNCRI & DINVPROTECTION \\
\hline Australia & 338 & -5.666 & 0.069 & 1 & 1 \\
\hline Austria & 48 & -18.188 & -0.047 & 0 & 0 \\
\hline Belgium & 57 & -0.404 & -0.038 & 0 & 0 \\
\hline Canada & 324 & -16.765 & 0.549 & 1 & 1 \\
\hline China & 32 & -54.938 & 0.0001 & 0 & 0 \\
\hline Denmark & 59 & 1.237 & 2.908 & 1 & 0 \\
\hline Finland & 97 & 11.628 & 4.549 & 1 & 0 \\
\hline France & 334 & 10.937 & 0.743 & 0 & 0 \\
\hline Germany & 318 & -11.321 & 88.747 & 1 & 0 \\
\hline Greece & 24 & 1.167 & 0.001 & 0 & 0 \\
\hline Hong-Kong & 394 & -48.690 & 9.459 & 0 & 1 \\
\hline Ireland & 39 & -25.026 & 0.232 & 1 & 0 \\
\hline Italy & 123 & 4.919 & 17.426 & 0 & 0 \\
\hline Japan & 1881 & -20.074 & 0.034 & 0 & 0 \\
\hline Luxembourg & 6 & -37.000 & 0.029 & 1 & 0 \\
\hline Netherlands & 78 & 15.231 & 0.678 & 1 & 0 \\
\hline New Zealand & 44 & -11.727 & 0.018 & 1 & 1 \\
\hline Norway & 53 & 10.208 & 0.018 & 1 & 0 \\
\hline Portugal & 23 & 6.261 & 0.018 & 0 & 0 \\
\hline Singapore & 185 & -47.189 & 0.821 & 0 & 0 \\
\hline South Korea & 20 & 17.100 & 0.034 & 0 & 0 \\
\hline Spain & 108 & 0.639 & 0.048 & 0 & 0 \\
\hline Sweden & 120 & 3.250 & 0.063 & 1 & 0 \\
\hline Switzerland & 122 & -0.746 & -0.002 & 1 & 0 \\
\hline UK & 1634 & -8.139 & 8.048 & 1 & 1 \\
\hline USA & 2324 & -20.789 & 11.129 & 0 & 1 \\
\hline
\end{tabular}


Table 4. The combined effect EM and CSR Practices on cost of capital (MODEL A: Cost of capital, Arellano Bond GMM)

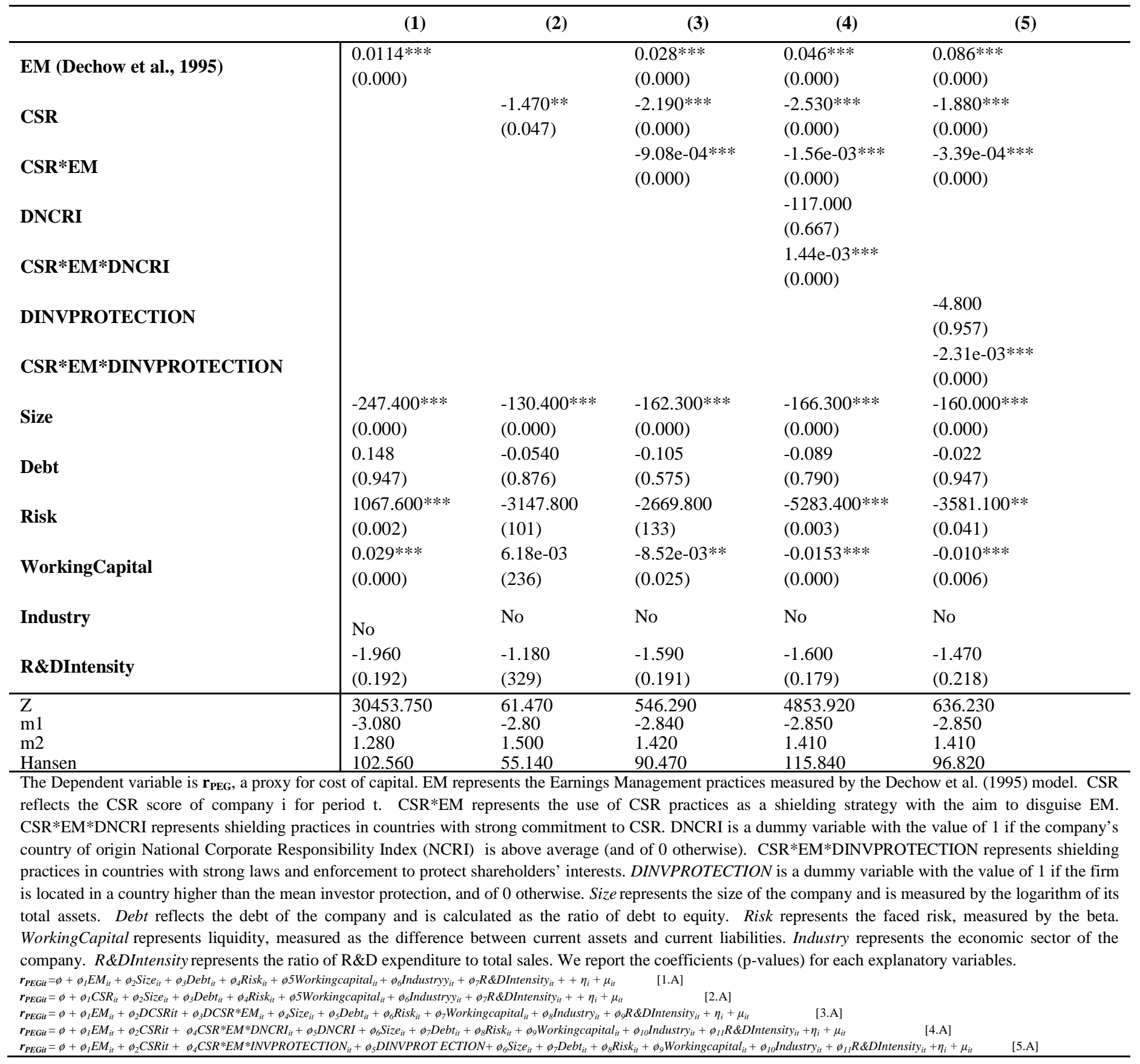


Table 6. Robust Analysis. Civil Vs Common Law. The combined effect EM and CSR Practices on the Cost of Capital and Corporate Reputation

\begin{tabular}{|c|c|c|c|c|c|c|c|c|}
\hline & \multicolumn{4}{|c|}{ MODEL A: COST OF CAPITAL } & \multicolumn{4}{|c|}{ MODEL B: CORPORATE REPUTATION } \\
\hline & \multicolumn{2}{|c|}{ COMMON LAW } & \multicolumn{2}{|c|}{ CIVIL LAW } & \multicolumn{2}{|c|}{ COMMON LAW } & \multicolumn{2}{|c|}{ CIVIL LAW } \\
\hline & Coef. & $\mathrm{P}>|\mathrm{Z}|$ & Coef. & $\mathrm{P}>|\mathrm{Z}|$ & Coef. & $\mathrm{P}>|\mathrm{Z}|$ & Coef. & $\mathrm{P}>|\mathrm{Z}|$ \\
\hline$E M$ & $0.266 * * *$ & 0.000 & $0.0131 * * *$ & 0.000 & -140.500 & 0.758 & $-8951.300 *$ & 0.071 \\
\hline CSR & -0.506 & 0.635 & $-3.480 * * *$ & 0.000 & 2617.800 & 0.460 & $53.2 \mathrm{E}+3^{* * *}$ & 0.000 \\
\hline$C S R^{*} E M$ & $-7.77 \mathrm{E}-03^{* * *}$ & 0.000 & $3.85 \mathrm{E}-04 * * *$ & 0.000 & 1.890 & 0.867 & -117.000 & 0.104 \\
\hline Size & $-217.700 * * *$ & 0.000 & $-170.790 * * *$ & 0.000 & $91.15 \mathrm{E}+4 * * *$ & 0.000 & $29.53 \mathrm{E}+4^{* * *}$ & 0.001 \\
\hline Debt & 0.199 & 0.488 & $7.110^{* * *}$ & 0.000 & -4994.800 & 0.382 & -3453.900 & 0.390 \\
\hline Risk & -18078.1 & 0.385 & 88.300 & 0.808 & $-58.89 E+3$ & 0.673 & -6.310 & 0.998 \\
\hline WorkingCapital & $0.002^{* * *}$ & 0.000 & $2.28 \mathrm{E}-04$ & 0.972 & $387.400 * * *$ & 0.000 & $301.800 * * *$ & 0.001 \\
\hline Industry & \multicolumn{2}{|c|}{ No } & \multicolumn{2}{|c|}{ No } & \multicolumn{2}{|c|}{ Yes } & \multicolumn{2}{|c|}{ Yes } \\
\hline R\&DIntensity & $22.000 * *$ & 0.046 & $-1.630^{* * *}$ & 0.000 & -7884.800 & 0.551 & 5767.600 & 0.936 \\
\hline Intercept & & & & & $-13.8 \mathrm{E}+6^{* * *}$ & 0.000 & $-12.94 \mathrm{E}+6 * * *$ & 0.000 \\
\hline $\begin{array}{l}\mathrm{Z} \\
\mathrm{m} 1 \\
\mathrm{~m} 2 \\
\text { Hansen } \\
\end{array}$ & $\begin{array}{c}3379.430 \\
-2.710 \\
1.260 \\
98.110 \\
\end{array}$ & & $\begin{array}{c}125.490 \\
-1.460 \\
-1.240 \\
96.260 \\
\end{array}$ & & & & & \\
\hline $\begin{array}{l}\text { We run the followin } \\
r_{P E G i t}=\varnothing+\varnothing_{1} E M_{i t} \\
\text { REPUTATION } \\
\text { See tables } 4 \text { and } 5\end{array}$ & $\begin{array}{l}\text { two models for Co } \\
\emptyset_{2} D C S R i t+\emptyset_{3} D C s \\
\emptyset_{1} E M_{i t}+\emptyset_{2} D C S R \\
\text { a short explanatic }\end{array}$ & $\begin{array}{l}\text { non law and } \\
{ }^{k} E M_{i t}+\varnothing_{4} S i \\
+\emptyset_{3} D C S R^{*} I \\
\text { of the variab }\end{array}$ & $\begin{array}{l}\text { il law country. T } \\
+\emptyset_{5} \text { Debt }_{i t}+\emptyset_{6} R \\
+\emptyset_{4} \text { Size }_{i t}+\emptyset_{5} D \\
\text { We report the co }\end{array}$ & $\begin{array}{l}\text { first is an } \\
\text { it }+\emptyset_{7} \text { Work } \\
t_{i t}+\emptyset_{6} \text { Risk } \\
\text { icients (p-v }\end{array}$ & $\begin{array}{l}\text { abo Bond GMM n } \\
\text { apital }_{\text {it }}+\varnothing_{8} \text { Indust } \\
{ }_{7} \text { Workingcapital }_{\text {it }} \\
\text { s) for each explan }\end{array}$ & $\begin{array}{l}\text { el and the sec } \\
+\emptyset_{9} R \& D I n t e r \\
\text { Industry } \\
\text { y variables. }\end{array}$ & $\begin{array}{l}\text { logit model: } \\
\eta_{i}+\mu_{i t} \\
\text { ntensity }_{i t}+\eta_{i}+\mu_{i t}\end{array}$ & \\
\hline
\end{tabular}

